\title{
MANAJEMEN KAS BERBASIS VIRTUAL ACCOUNT PADA PT PLN (PERSERO) UPP PEMBANGKIT JAWA BAGIAN BARAT
}

\author{
TRI WAHYUDI \\ Universitas Sultan Ageng Tirtayasa, Serang, Indonesia \\ Email: tri.wahyudi@untirta.ac.id
}

\begin{abstract}
The company's operational activities can run optimally if cash is managed properly. In the cash of PT PLN (Persero) UPP Pembangkit Jawa Barat there is petty cash which is used to finance the company's operational activities of small value. The purpose of this study was to determine petty cash management based on the virtual account system at PT PLN (Persero) Unit Pelaksana Proyek (UPP) Pembangkit Jawa Bagian Barat so that it could see the cash management process more effectively and efficiently. This research is descriptive in nature, namely research by describing the condition of the company based on actual conditions. From the results of this study, it was found that PT PLN (Persero) Unit Pelaksana Proyek (UPP) Pembangkit Jawa Bagian Barat uses a cash management system with the Imprest system by determining the petty cash value that has been determined per week by PT PLN (Persero) Unit Induk Pembangunan (UIP) Jawa Bagian Barat. Petty cash is taken using an ATM card media which can only be withdrawn for petty cash during working hours and days. Cash management through virtual accounts really helps the cash management process in real time and minimizes idle cash.
\end{abstract}

Keywords: petty cash, virtual accounts, cash management

\section{PENDAHULUAN}

Tidak dapat dipungkiri perkembangan bisnis yang semakin pesat dan berdaya saing tinggi menuntut setiap perusahaan untuk menciptakan keunggulan. Untuk mengembangkan bisnis agar dapat bersaing, maka perusahaan harus mampu mengelola dan melaksanakan manajemen perusahaan secara lebih efektif dan efisien, terutama dalam pengelolaan sumber daya yang dimiliki. Setiap perusahaan memiliki sumber daya, salah satunya adalah sumber daya keuangan (Effendy, 2021). Perusahaan membuat laporan keuangan yang merupakan cerminan dari kondisi perusahaan tersebut. Perusahaan diharapkan dapat mengelola aset yang dimiliki dengan sebaik mungkin untuk dapat mengoptimalkan laba (Rondonuwu sintje, 2018). Perusahaan yang memiliki ruang lingkup yang luas perlu mengelola keuangan dengan baik, prosedur pengelolaan aset sangat dibutuhkan oleh setiap perusahaan (F. I. Sari \& Sutiono, 2017) 
Sistem dan prosedur yang memadai dalam pengelolaan sumber daya keuangan sangat dibutuhkan untuk perusahaan agar dapat lebih unggul dan maju. Pengelolaan keuangan di dalam perusahaan merupakan dasar yang kuat untuk perkembangan suatu perusahaan (Oktavianna \& Prasetya, 2021). Perusahaan dalam mengelola keuangan membutuhkan informasi yang cepat, tepat dan akurat sehingga kebutuhan teknologi informasi sangat lah mutlah dibutuhkkan oleh perusahaan(Suwandi et al., 2019).

Aktivitas operasional perusahaan tidak dapat dipisahkan dari aktivitas yang berhubungan dengan kas. Kebutuhan pembiayaan itu, berhubungan dengan kas yang diperoleh dari kegiatan operasi serta pemodalan yang ada pada arus kas (Marviana \& Amalia, 2021).Kas merupakan bagian dari sumber daya keuangan yang sangat penting sehingga harus dikelola dengan baik untuk menopang kelangsungan hidup perusahaan (Y. P. L. Sari \& Suprayogi, 2020). Menimbang untuk efisiensi penggunaan cek dalam perusahaan, maka dibentuklah dana kas kecil atau petty cash sebagai dana kas yang digunakan untuk membiayai kebutuhan yang berjumlah kecil (Atika \& Pusung, 2018). Kas kecil sebaiknya tetap menggunakan perencanaan dan monitoring khusus untuk memenuhi kebutuhan perusahaan yang sifatnya mendesak dengan intensitas yang tinggi (Djauhar et al., 2021).

Untuk mempermudah sistem kerja dari pengelolaan dana kas kecil perlu ada campur tangan dari penggunaan teknologi (Darwis et al., 2020). Penemuan teknologi komputer dan informatika sejak awal dimaksudkan untuk membantu menrin-gankan pekerjaan manusia agar lebih efektif dan efisien (Putra \& Bakhar, 2021). Pengolahan dataTeknologi menjadikan sistem terkomputerisasi sehingga pengolahan dan penyimpanan data dengan kapasitas besar (Achyani \& Velayati, 2020). Kegiatan penerimaan dan pengeluaran kas merupakan hal yang sangat penting sehingga dibutuhkan sistem informasi arus kas yang dapat meningkatkan kecepatan dan ketepatan dalam pengolahan data-data penerimaan dan pengeluaran kas (Rusdi \& Andriani, 2021).

PT PLN (Persero) merupakan badan usaha milik negara yang menangani aspek tenaga listrik yang ada di Indonesia. Ruang lingkup kerja PT PLN (Persero) sangat luas sehingga dibutuhkan pengelolaan sumber daya yang baik, terutama sumber daya keuangannya. PT PLN (Persero) Unit Pelaksana Proyek (UPP) Pembangkit Jawa Bagian Barat merupakan unit pelaksana dibawah PT PLN (Persero) Unit Induk Pembangunan (UIP) Jawa Bagian Barat yang bertugas untuk membangun pembangkit di wilayah jawa bagian barat. Fungsi kas kecil sangatlah penting untuk memperlancar kegiatan operasional di PT PLN (Persero) Unit Pelaksana Proyek (UPP) Pembangkit Jawa Bagian Barat.

PT PLN (Persero) Unit Pelaksana Proyek (UPP) Pembangkit Jawa Bagian Barat memiliki program yang disebut Pemusatan Pengelolaan Fungsi Administrasi (PPFA) sehingga untuk setiap transaksi termasuk kas kecil dilakukan melalui virtual account dan menggunakan cash card sebagai alat transaksi penarikan tunai. Tujuan virtual account adalah untuk mengendalikan pemberian limit debet (transaksi) sehingga tidak perlu membuka banyak rekening serta memudahkan dalam kontrol pengeluaran kas kecil (Hana, 2021). Virtual account yang akan merupakan hasil koordinasi antara PT PLN (Persero) Unit Induk Pembangunan (UIP) Jawa Bagian Barat dengan PT PLN (Persero) Unit 
Pelaksana Proyek (UPP) Pembangkit Jawa Bagian Barat (Unit Pelaksana) serta Bank BNI (selaku Bank yang ditunjuk dalam cash management).

Pengelolaan kas kecil pada PT PLN (Persero) Unit Pelaksana Proyek (UPP) Pembangkit Jawa Bagian Barat berjalan dengan mengikuti setiap prosedur dan kebijakan yang ada. Dan ditemukan satu hambatan atau kendala yaitu tidak dapat dilakukan pengambilan kas kecil dihari dan jam selain jam kerja. Hal ini dikarenakan dalam pengalokasian kas kecil dilakukan dropping (pengisian) di hari senin oleh PT PLN (Persero) Unit Induk Pembagunan (UIP) Jawa Bagian Barat, kemudian dilakukan sweeping (penarikan) pada sisa kas kecil di hari Kamis oleh PT PLN (Persero) Unit Induk Pembagunan (UIP) Jawa Bagian Barat. Berdasarkan hal tersebut perlu diketahui terlebih dahulu seperti apa sistem pengelolaan kas kecil yang diterapkan dan prosedur seperti apa yang dilakukan dalam pengelolaan kas kecil di PT PLN (Persero) Unit Pelaksana Proyek (UPP) Pembangkit Jawa Bagian Barat. Sehingga dapat disimpulkan tujuan dari penelitian ini adalah untuk mengetahui sistem pengelolaan kas kecil yang diterapkan, untuk mengetahui prosedur yang dilakukan dalam pengelolaan kas kecil berbasis virtual account dan penyelesaian seperti apa yang selama ini dilakukan oleh PT PLN (Persero) Unit Pelaksana Proyek (UPP) Pembangkit Jawa Bagian Barat dalam menghadapi hambatan atau kendala yang terjadi.

\section{LANDASAN TEORI}

Sistem merupakan komponen-komponen yang saling terpaut dan berkorelasi guna tercapainya suatu tujuan (Romney, M.B. dan Steinbart, 2015). Sistem merupakan jaringan metode yang dilakukan menurut pola terintegrasi untuk mengembangkan bisnis utama perusahaan (Mulyadi, 2016). Akuntansi sebagai suatu sistem informasi yang menyediakan laporan tentang peristiwa dan kondisi ekonomi perusahaan. Akuntansi juga diartikan sebagai proses menemukan, mengumpulkan, dan menyimpan data dan mengembangkan, menganalisis, dan mengkomunikasikan informasi (Romney, M.B. dan Steinbart, 2015).

Definisi sistem akuntansi adalah bahwa sistem akuntansi adalah komposisi formulir, catatan, dan laporan yang dimaksudkan untuk memberikan informasi keuangan untuk manajemen bisnis perusahaan (Mulyadi, 2016). Sistem akuntansi juga merupakan cara untuk menangkap, menyusun, mensintesis, dan mengkomunikasikan informasi keuangan dan operasional perusahaan. Sistem akuntansi memiliki tujuan sebagai berikut:

1. Untuk memberikan informasi bagi pengelolaan aktivitas usaha baru.

2. Meningkatkan informasi yang dihasilkan oleh sistem yang ada baik dari segi kualitas data, akurasi dan basis data.

3. Untuk meningkatkan tingkat keandalan informasi akuntansi perusahaan.

4. Pengurangan biaya klerikal. (Mulyadi, 2016)

Prosedur merupakan suatu aktivitas klerikal, umumnya melibatkan beberapa orang dalam satu bagian atau lebih yang dirancang untuk memastikan keseragaman penanganan transaksi perusahaan yang berulang. Prosedur merupakan suatu instruksi yang berisi prosedur operasional organisasi untuk memastikan bahwa semua keputusan dan tidakan yang diambil oleh internal organisasi sudah efektif, efisien, stabil, standar dan teratur (Tambunan, 2013).

* Corresponding author's e-mail: tri.wahyudi@untirta.ac.id http://openjournal.unpam.ac.id/index.php/JIA 
Kas merupakan harta perusahaan yang terdiri dari uang kertas, logam dan cek atau uang yang ada ditangan atau dalam deposito. Ada kalanya kas disimpan untuk tujuan tertentu, sehingga tidak bebas untuk digunakan dalam operasional perusahaan dan hanya untuk penggunaan khusus, sehingga tidak boleh diklasifikasikan sebagai kas tetapi sebagai dana cadangan (Martani, 2018).

Kas kecil merupakan dana tunai yang sengaja dipisahkan oleh perusahaan untuk memproses pembayaran yang bernilai kecil (Hamizar, 2015). Penggunaan cek untuk kas kecil dinilai tidak ekonomis karena kas kecil adalah dana yang disiapkan untuk pengeluaran kecil yang bersifat rutin dan berkala (Effendi, 2015). Kas kecil dibentuk oleh perusahaan hanya untuk pembayaran-pembayaran yang berjumlah kecil sedangkan untuk pembayaran yang berjumlah besar, perusahaan biasanya menggunakan cek (Atika \& Pusung, 2018). Dana kas yang diserahkan kepada pemegang kas kecil perusahaan akan bertanggung jawab penuh atas pengeluaran dan penggunaan kas kecil selama periode tertentu (Suranti, 2016). mempengaruhi kas. Selain itu baik kas atau kas kecil mudah untuk dipindahtangankan sehingga mudah pula untuk digelapkan dan dimanipulasi (Wulandari \& Khabibah, 2020). Atau bisa juga diartikan adanya kas kecil dimungkinkan untuk membeli inventaris, menjualnya, dan menerima serta mengeluarkan uang tunai dalam waktu yang lebih singkat (Manajemen et al., 2021).

Pengelolaan kas kecil dapat dilakukan dengan dua cara, yaitu Fluctuating System dan Imprest System. Dalam Fluctuating system, tidak ada jumlah tertentu yang ditetapkan untuk dana kas kecil, karena hal itu saldonya beragam dari waktu ke waktu. Dan penggantian dilakukan tidak tergantung pada jumlah yang telah digunakan, tetapi tergantung pada jumlah yang diperlukan saja sehingga saldo atas kas kecil akan berubah-ubah. Sedangkan dalam Imprest System merupakan sistem kas kecil dimana dananya tetap konstan. Pada saat terjadi pengeluaran kas kecil dibuatkan bukti pengeluaran. Awalnya, dana kas kecil dibentuk dalam jumlah tertentu, dan nantinya akan dilakukan penggantian saat kas kecil akan habis sesuai dengan jumlah yang sudah digunakan sehingga nantinya dana kas kecil akan kembali sejumlah yang telah ditentukan sebelumnya (Martani, 2018). Dalam konteks pengendalian, penggunaan sistem imprest dinilai lebih baik karena jumlah uang tunai atas kas kecil dikendalikan dan tidak ada penumpukan uang yang tidak terpakai, dan pengendalian pun terjadi karena dilakukan penghitungan pada kas kecil yang terpakai dan tersisa pada saat penggantian sehingga dapat dipantau pada pemakaian kas kecil. sedangkan, dalam Fluctuating System jumlah dananya tidak terkendali dan jumlahnya dapat terus bertambah apabila dana tidak digunakan (Martani, 2018). Dokumen, fungsi dan prosedur yang biasanya digunakan dalam sistem pengelolaan dana kas kecil yakni:

Dokumen Sistem Pengelolaan Dana Kas Kecil, meliputi :

1) Bukti kas keluar,

2) Cek

3) Permintaan pengeluaran kas kecil

4) Bukti pengeluaran kas kecil.

5) Permintaan pengisian kembali kas kecil. 
Fungsi Sistem Pengelolaan Dana Kas Kecil, meliputi :

1) Fungsi kas

2) Fungsi akuntansi

3) Fungsi pemegang dana kas kecil

4) Fungsi pemeriksaan intern.

Prosedur Sistem Pengelolaan Dana Kas Kecil, meliputi :

1) Prosedur pembentukan dana kas kecil

2) Prosedur permintaan kas kecil

3) Prosedur pertanggungjawaban pengeluaran kas kecil

4) Prosedur pengisian kembali kas kecil. (Mulyadi, 2016)

Virtual account merupakan rekening yang dibuatkan oleh Bank atas permintaan perusahaan untuk diberikan kepada customer. Virtual account itu sendiri berisikan nomor ID customer. Manfaat dari penggunaan virtual account sendiri untuk mempermudah dalam rekonsilasi, pengendalian transaksi dan mempercepat pengimplementasian dengan mudah.

\section{METODE PENELITIAN}

Metode yang digunakan dalam penelitian ini adalah metode deskriptif, dimana dengan memaparkan atau menggambarkan suatu keadaaan yang sebenarnya terjadi. Dengan kata lain penelitian ini dilakukan untuk memaparkan atau menggambarkan seperti apa implementasi pengelolaan kas kecil berbasis virtual account di PT PLN (Persero) Unit Pelaksana Proyek (UPP) Pembangkit Jawa Bagian Barat. Dan penelitian ini berisi paparan hasil penelitian yang telah dilaksanakan oleh penulis di PT PLN (Persero) Unit Pelaksana Proyek (UPP) Pembangkit Jawa Bagian Barat serta dikaitkan dengan teori-teori menurut para ahli akuntansi.

Sumber data yang digunakan dalam penelitian ini adalah studi lapangan dan studi pustaka. Studi lapangan dengan melakukan peninjauan secara langsung ke tempat objek penelitian yaitu PT PLN (Persero) Unit Pelaksana Proyek (UPP) Pembangkit Jawa Bagian Barat. Dan studi pustaka dengan dilakukan pengumpulan data yang relevan dari banyak referensi dan mempelajari yang berkaitan dengan masalah yang akan dibahas pada penelitian ini. Data diperoleh secara langsung dengan melakukan kerja praktik serta penelitian di lapangan guna mendapatkan data-data yang dibutuhkan dalam proses penelitian ini.

Metode pengumpulan data yang digunakan adalah dengan wawancara, dokumentasi dan observasi. Metode wawancara yang dilakukan adalah wawancara tidak terstruktur yang mana dengan mewawancarai secara langsung partisipan yang bersangkutan di PT PLN (Persero) Unit Pelaksana Proyek (UPP) Pembangkit Jawa Bagian Barat, dengan wawancara ini didapatkan informasi langsung dari pihak yang bersangkutan sehingga informasi dapat dikelola dan pemecahan masalah lebih mudah dilakukan. Dokumentasi dilakukan dengan menggunakan dokumen yang sudah ada pada PT PLN (Persero) Unit Pelaksana Proyek (UPP) Pembangkit Jawa Bagian Barat. Observasi dilakukan dengan mengamati secara langsung pada PT PLN (Persero) Unit Pelaksana Proyek (UPP) Pembangkit Jawa Bagian Barat yang dijadikan sebagai sumber data yang digunakan dalam penelitian ini. 


\section{HASIL DAN PEMBAHASAN}

Pengelolaan kas di PT PLN (Persero) Unit Pelaksana Proyek (UPP) Pembangkit Jawa Bagian Barat awalnya hanya menggunakan sistem transfer ke rekening, Sistem transfer tersebut mengharuskan penggunaan bilyet giro serta cek untuk bertransaksi sehingga dirasakan ketidakefektifan dan ketidakefisienan dalam bertransaksi, karena membutuhkan tambahan waktu untuk menyiapkan bilyet giro atau cek serta mengantri di bank Penggunaan bilyet giro serta cek untuk setiap transaksi baik itu dengan nominal transaksi nilai besar dan kecil. Adanya sistem manajemen kas dengan berbasis pada virtual account pada PT PLN (Persero) Unit Pelaksana Proyek (UPP) Pembangkit Jawa Bagian Barat memudahkan dalam menjalankan operasional keuangan perusahaan, karena dengan sistem ini semua pengeluaran sudah terencana secara terpusat dengan unit induk dalam hal ini adalah PT PLN (Persero) Unit Induk Pembangunan (UIP) Jawa Bagian Barat

PLN (Persero) Unit Pelaksana Proyek (UPP) Pembangkit Jawa Bagian Barat dalam menjalankan operasionalnya menggunakan virtual account untuk menunjang sistem manajemen kas yang ada di perusahaan dengan besaran yang sudah ditetapkan PT PLN (Persero) Unit Induk Pembagunan (UIP) Jawa Bagian Barat ialah sebesar Rp100.000.000 (seratus juta rupiah) per bulan yang dibagi kedalam 4 (empat) periode atau sama dengan Rp.25.000.000 (dua puluh lima juta rupiah) per minggu. Sistem virtual account lebih dikenal dengan istilah cash card lebih dirasakan manfaatnya untuk membiayai transaksi dengan nilai nominal kecil yaitu sampai dengan Rp10.000.000 (sepuluh juta rupiah) untuk setiap kuitansi. Waktu yang digunakan dalam menjalankan kegiatan operasional perusahaan dengan menggunakan cash card juga lebih efektif dan efisien. Kekurangan dengan kondisi penggunaan cash cash sekarang adalah belum bisa melakukan transaksi dengan nilai di atas Rp10.000.000 (sepuluh juta rupiah) sehingga belum optimal dalam hal fleksibilitas transaksi dan waktu. Selain itu sistem pengambilan uang (penggunaan cash card) yang harus di hari dan jam kerja terkadang menjadi hambatan tersendiri ketika membutuhkan uang di luar hari dan jam kerja untuk kebutuhan operasional pekerjaan.

\section{Sistem dan Penetapan Saldo}

Sistem pengelolaan kas kecil yang diterapkan di PT PLN (Persero) Unit Pelaksana Proyek (UPP) Pembangkit Jawa Bagian Barat adalah sistem imprest. Besaran kas kecil sudah ditetapkan oleh Unit Induk atau PT PLN (Persero) Unit Induk Pembagunan (UIP) Jawa Bagian Barat yakni sebesar Rp100.000.000 (seratus juta rupiah) per bulan yang dibagi kedalam 4 periode atau sama dengan Rp25.000.000 (dua puluh lima juta rupiah) per minggu.

Kas Kecil dikirim oleh Unit Induk melalui virtual account yang sudah dibuatkan oleh Bank Mitra untuk PT PLN (Persero) Unit Pelaksana Proyek (UPP) Pembangkit Jawa Bagian Barat. Dan kas kecil yang disediakan sudah dalam bentuk cash card atau kartu ATM sehingga PT PLN (Persero) Unit Pelaksana Proyek (UPP) Pembangkit Jawa Bagian Barat dapat langsung melakukan pengambilan kas kecil melaui Mesin ATM atau melalui teller Bank dengan menunjukan kartu pegawai. Dan pada saat pengeluaran kas kecil semua bukti-

* Corresponding author's e-mail: tri.wahyudi@untirta.ac.id http://openjournal.unpam.ac.id/index.php/JIA 
bukti pengeluaran kas kecil seperti struk ATM, bukti penarikan dari bank, dan nota atau kuitansi dari pembelian yang menggunakan kas kecil akan disimpan atau diarsip.

\section{Dokumen yang Digunakan}

Dokumen yang digunakan dalam sistem dana kas kecil pada PT PLN (Persero) meliputi:

1) Dokumen permintaan pengeluaran kas kecil

2) Bukti pengeluaran kas kecil

3) Laporan Realisasi Kas Kecil

4) Dokumen permintaan pengisian kembali kas kecil.

\section{Fungsi yang Terkait}

Fungsi yang terkait dalam sistem dana kas kecil di PT PLN (Persero) Unit Pelaksana Proyek (UPP) Pembangkit Jawa Bagian Barat meliputi:

1) Fungsi kas

2) Fungsi akuntansi

3) Fungsi pemegang dana kas kecil

4) Fungsi pengguna kas kecil

5) Fungsi penanggung jawab kas kecil

\section{Prosedur Pengelolaan Kas Kecil}

PT PLN (Persero) Unit Pelaksana Proyek (UPP) Pembangkit Jawa Bagian Barat dalam pengelolaan kas kecilnya dilakukan melalui 4 prosedur yaitu:

1) Prosedur pembentukan kas kecil

2) Prosedur pengajuan kas kecil

3) Prosedur pertanggungjawaban kas kecil

4) Prosedur pengisian kembali kas kecil.

\section{Prosedur Pembentukan Kas Kecil}

Dalam prosedur pembentukan kas kecil dimulai dengan ditetapkannya limit kas kecil oleh Unit Induk yakni sebesar Rp100.000.000 (seratus juta rupiah) per bulan atau sama dengan Rp25.000.000 (dua puluh lima juta rupiah) per minggu yang kemudian akan disampaikan limit kas kecil tersebut ke Bank Mitra (BRI) yang nantinya akan dilakukan setting limit oleh BRI. Kemudian kas kecil akan dikirim oleh Unit Induk melalui BRI pada virtual account PT PLN (Persero) Unit Pelaksana Proyek (UPP) Pembangkit Jawa Bagian Barat yang nantinya dapat dilakukan pengambilan kas kecil melalui mesin ATM atau teller bank. Alur/ prosedur pembentukan kas kecil sebagaimana gambar 1. 

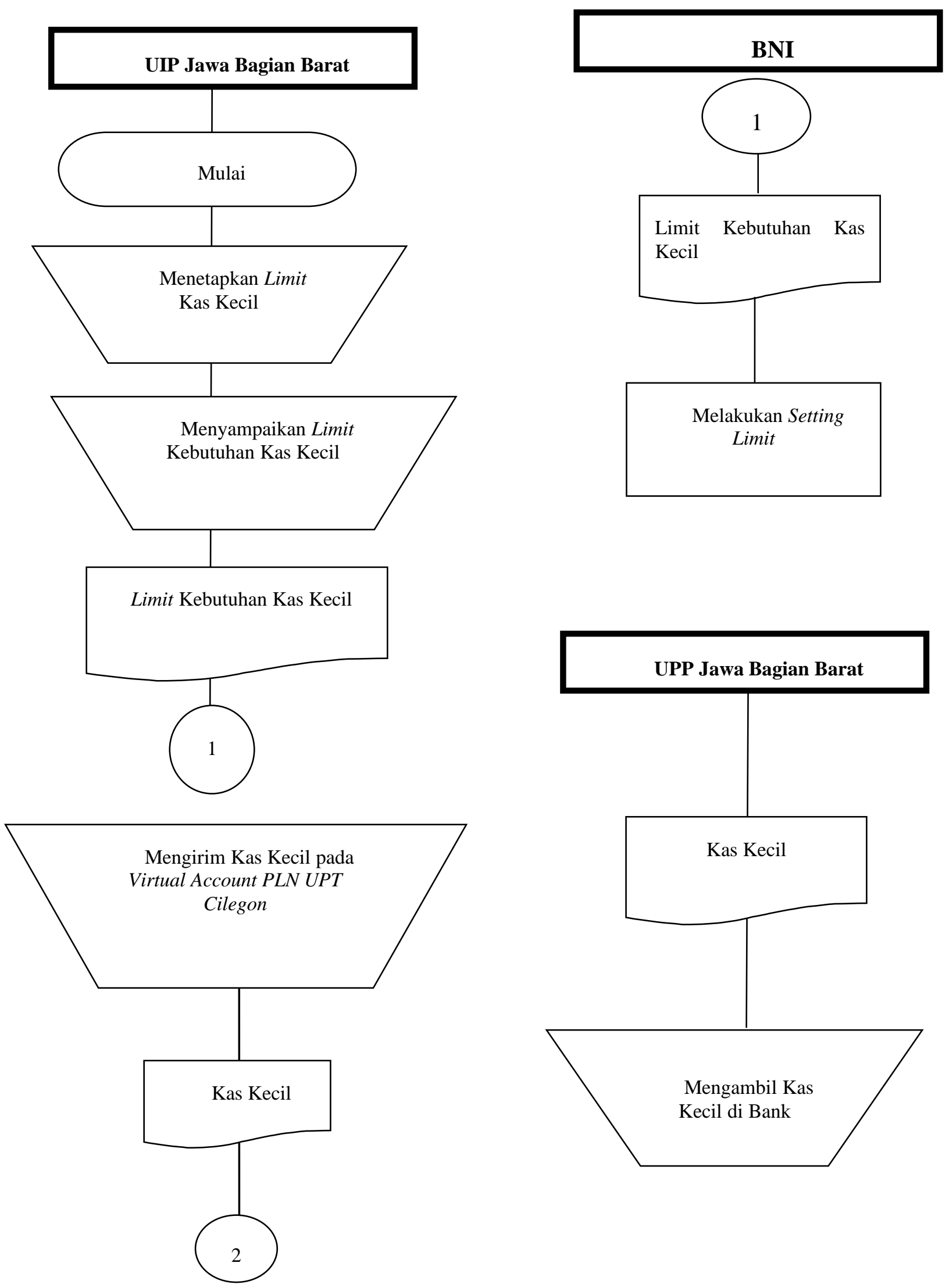

Sumber : Data diolah, 2021

Gambar 1 Prosedur Pembentukan Kas Kecil

* Corresponding author's e-mail: tri.wahyudi@untirta.ac.id http://openjournal.unpam.ac.id/index.php/JIA 


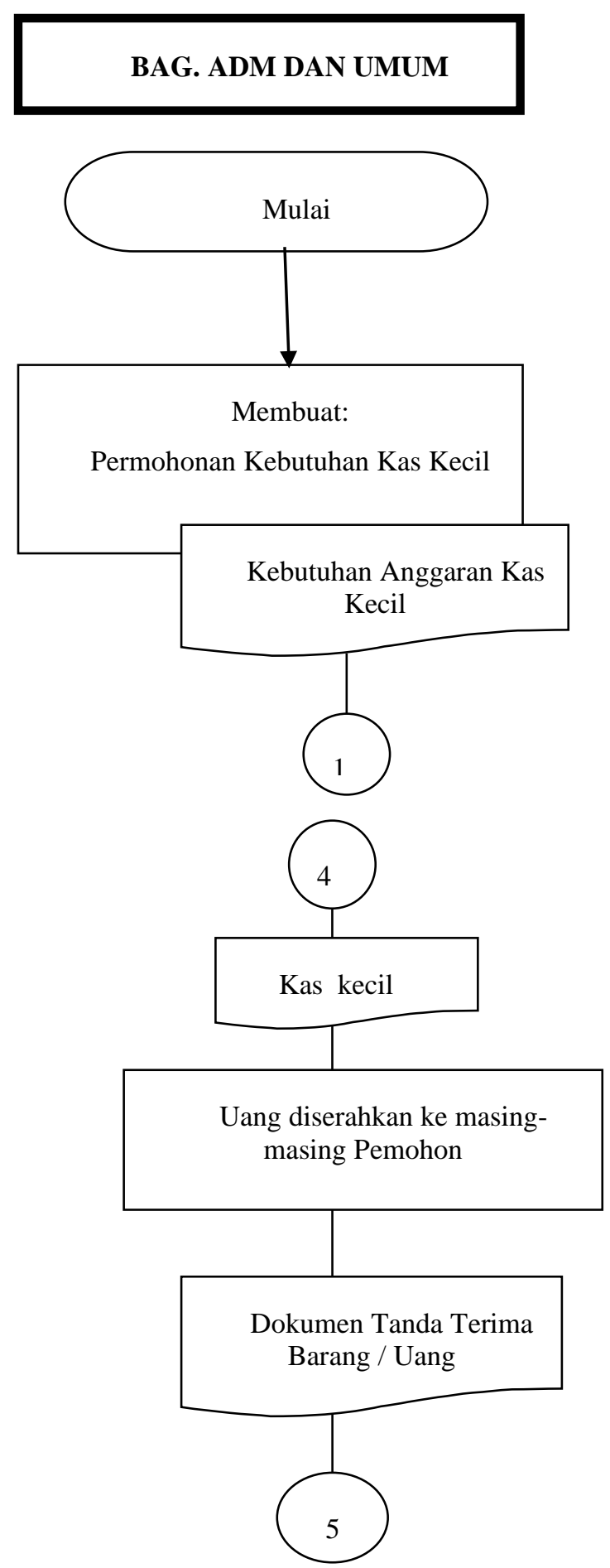

BAG. KEU DAN AKT

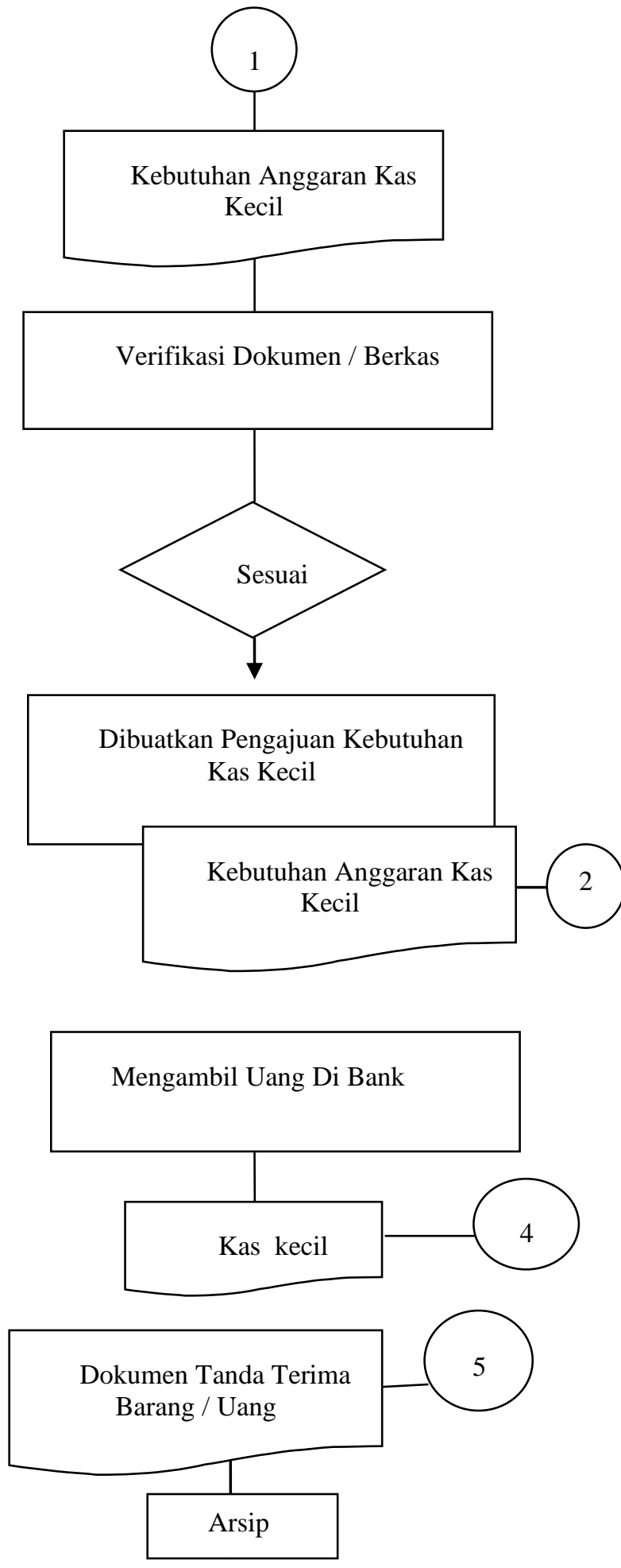

Sumber : Data diolah, 2021

Gambar 2 Prosedur Pengajuan Kas Kecil 


\section{Prosedur Pengajuan Kas Kecil}

Dalam prosedur pengajuan kas kecil dilakukan melalui tahapan sebagai berikut:

1) Bagian Administrasi dan Umum membuat Permohonan Kebutuhan Kas Kecil dengan lampiran dokumen Kebutuhan Anggaran Kas Kecil. Dokumen tersebut kemudian diserahkan ke Bagian Keuangan dan Akuntansi.

2) Bagian Keuangan dan Akuntansi memverifikasi dokumen tersebut untuk memastikan apakah sudah sesuai. Jika sudah sesuai maka akan dibuatkan Pengajuan Kebutuhan Kas Kecil. Dalam hal ini membutuhkan persetujuan dari Manager Keuangan dan Administrasi dan persetujuan Manager Unit Pelaksana.

3) Jika sudah mendapatkan persetujuan maka Bagian Keuangan dan Akuntansi dapat mengambil uang tersebut melalui Mesin ATM atau di Bank Melalui Teller dibuktikan dengan slip penarikan bank/struk ATM. Kemudian uang diserahkan kemasing-masing pemohon dan memberikan bukti pembelian dari toko atau mitra yang dapat dipertanggungjawabkan berupa nota print (struk) atau nota putih dan kwitansi dengan tulis tangan, TTD, Cap toko dan menggunakan materai. Semua dokumen tersebut kemudian disimpan / diarsip oleh Bagian Keuangan dan Akuntansi. Alur/ prosedur pengajuan kas kecil sebagaimana gambar 2 .

\section{Prosedur Pertanggungjawaban Kas Kecil}

Prosedur Pertanggungjawaban kas kecil dapat dilakukan melalui alur dan sebagaimana gambar 3 sebagai berikut :

1) Pada PLN Unit Pelaksana Proyek (UPP) Pembangkit Jawa Bagian Barat Pertanggungjawaban kas kecil dilakukan setiap akhir bulan. Pada akhir bulan Bagian Administrasi dan Umum membuat dokumenrealisasi kas kecil dengan dilampirkan berkas asli dokumen pembayaran dan bukti kas keluar kemudian diserahkan ke Bagian Keuangan dan Akuntansi.

2) Selanjutnya, Bagian Keuangan dan Akuntansi akan memverifikasi kelengkapan berkas kas kecil dan melakukan evaluasi kewajaran nilai dari pembelian barang yang tercantum serta keabsahan dokumen pertanggungjawaban. Jika berkas sudah lengkap maka akan dibuatkan Laporan Realisasi Kas Kecil.

3) Manager Unit Pelaksana membubuhkan tanda tangan dalam laporan bulanan tersebut. Kemudian Dokumen Pembayaran Kas Kecil tersebut diserahkan ke Bagian Keuangan dan Akuntansi untuk diarsip.

\section{Prosedur Pengisian Kembali Kas Kecil}

Dalam prosedur pengisian kembali kas kecil dilakukan melalui alur dan sebagaimana gambar 4 sebagai berikut :

1) PLN Unit Pelaksana Proyek (UPP) Pembangkit Jawa Bagian Barat melakukan evaluasi pengeluaran-pengeluaran yang sudah terjadi. Kemudian akan dibuatkan Rencana Kebutuhan Kas Kecil dengan nilai yang harus sama dengan pengeluaran yang sudah terjadi atau Realisasi Kas Kecil.

2) PLN Unit Pelaksana Proyek (UPP) Pembangkit Jawa Bagian Barat mengajukan kepada PLN UIT JBB, apabila disetujui PLN UIT JBB akan melakukan pengisian kas kecil ke rekening virtual account PLN Unit Pelaksana Proyek (UPP) Pembangkit Jawa Bagian Barat sebesar nilai pagu. 
3) PLN Unit Pelaksana Proyek (UPP) Pembangkit Jawa Bagian Barat dapat melakukan pengambilan kas kecil melalui mesin ATM atau melalui teller Bank BRI.

\section{Hambatan Yang Terjadi}

Pada PT PLN (Persero) Unit Pelaksana Proyek (UPP) Pembangkit Jawa Bagian Barat terdapat waktu dalam pengisian (dropping) dan Penarikan (sweeping) kas kecil setiap minggunya. Pada awal minggu atau hari Senin Unit Induk akan melakukan dropping dana sebesar Rp25.000.000 (dua puluh lima juta rupiah) dan diusahakan dana tersebut harus dihabiskan karena dalam Rencana Kebutuhan Kas Kecil untuk pengisian kembali nilainya harus sama dengan realisasi. PT PLN (Persero) Unit Pelaksana Proyek (UPP) Pembangkit Jawa Bagian Barat dapat menggunakan kas kecil sampai dengan hari kamis, karena pada hari kamis akan dilakukan sweeping pada sisa kas kecil oleh Unit Induk. Dana sisa disweeping oleh Unit Induk agar dapat dihabiskan untuk penggunaan lain. Karena hal itu, terhitung hari tersebut saldo dalam rekening akan berjumlah Rp0 sampai dengan dilakukan pengisian kembali di hari Senin. Karena hal itu, apabila pengguna membutuhkan kas kecil dihari jum'at, sabtu dan minggu maka sudah tidak dapat dilakukan pengambilan dana. Dan hal ini menimbulkan hambatan untuk menjalankan kegiatan operasional perusahaan.

\section{Penyelesaian Atas Hambatan Yang Terjadi}

Penyelesaian yang dilakukan oleh PT PLN (Persero) Unit Pelaksana Proyek (UPP) Pembangkit Jawa Bagian Barat selama ini adalah dengan pengguna kas kecil menggunakan uang pribadi miliknya untuk digunakan yang nantinya uang tersebut akan diganti pada saat kas kecil sudah tersedia kembali di hari Senin.

Dalam upaya untuk mencegah hambatan tersebut terjadi, biasanya pada hari sebelum dilakukan sweeping oleh Unit Induk, PT PLN (Persero) Unit Pelaksana Proyek (UPP) Pembangkit Jawa Bagian Barat akan memastikan terlebih dahulu apakah akan dilakukan pengambilan kas kecil pada hari kas kecil bersaldo Rp.0,dan apabila ada rencana untuk mengambil kas kecil dihari tersebut maka PT PLN (Persero) Unit Pelaksana Proyek (UPP) Pembangkit Jawa Bagian Barat akan mengkonfirmasi kepada Unit Induk sehingga nantinya pada saat dilakukan sweeping Unit Induk akan menyisakan saldo kas kecil sebesar yang dibutuhkan. 
Jurnal Ilmiah Akuntansi Universitas Pamulang - Vol. 9, No. 2 Juli 2021 - Tri Wahyudi

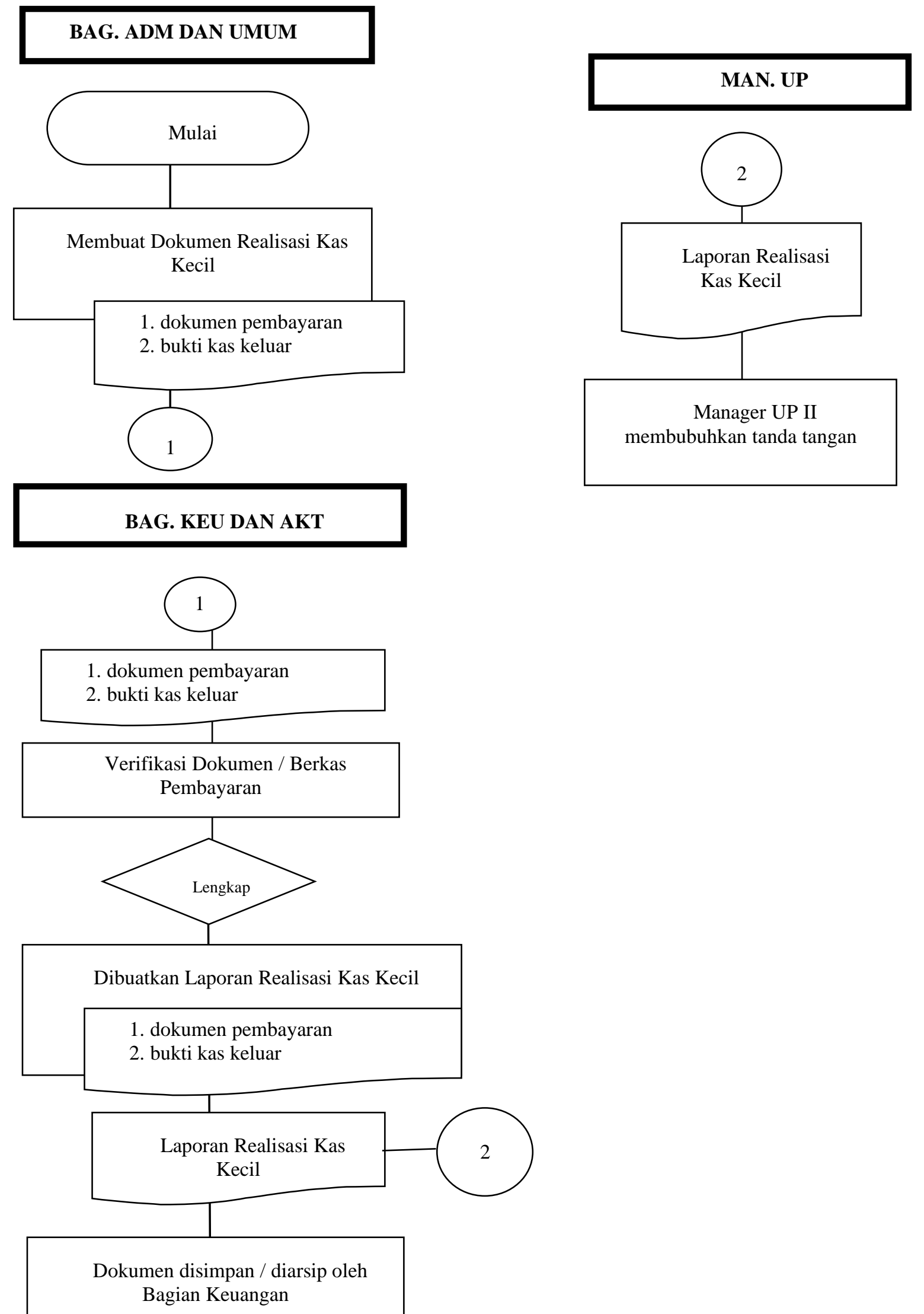

Sumber : Data diolah, 2021

Gambar 3 Prosedur Pertanggungjawaban Kas Kecil

* Corresponding author's e-mail: tri.wahyudi@untirta.ac.id http://openjournal.unpam.ac.id/index.php/JIA 
Jurnal Ilmiah Akuntansi Universitas Pamulang - Vol. 9, No. 2 Juli 2021 - Tri Wahyudi

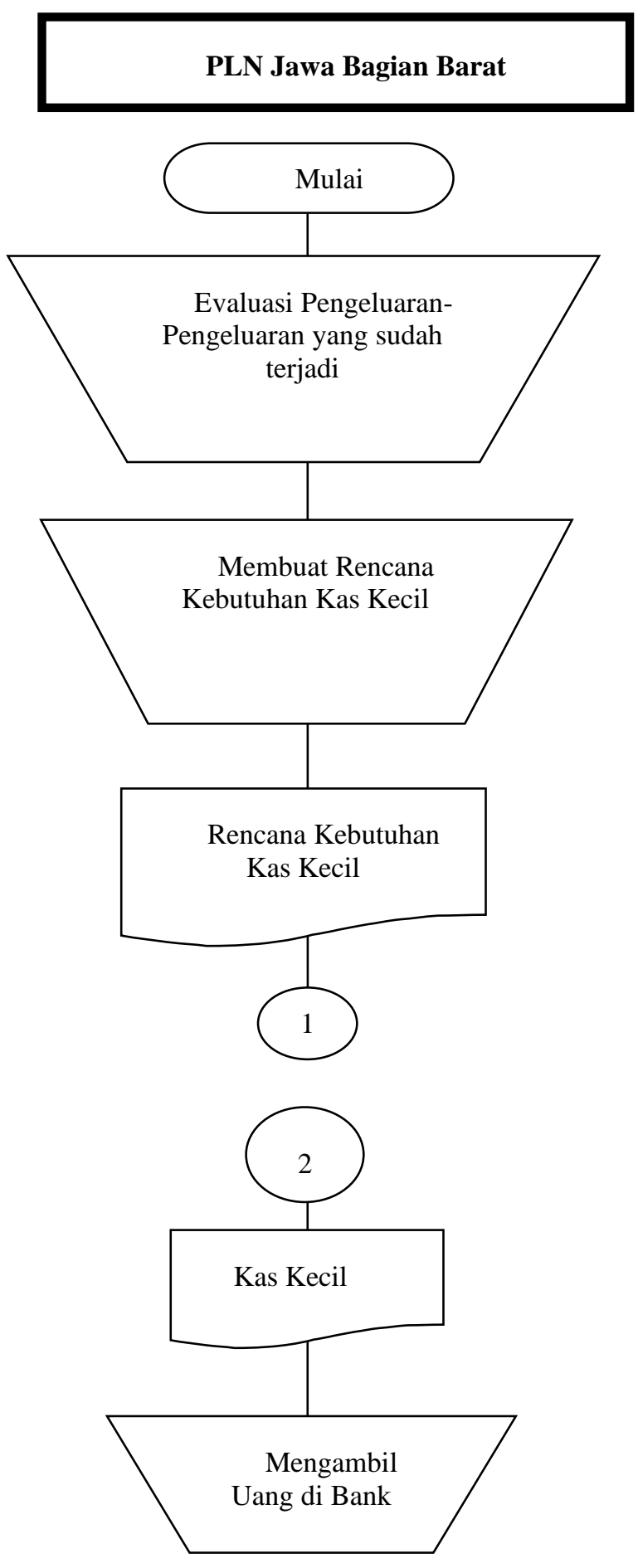

UIP Jawa Bagian Barat

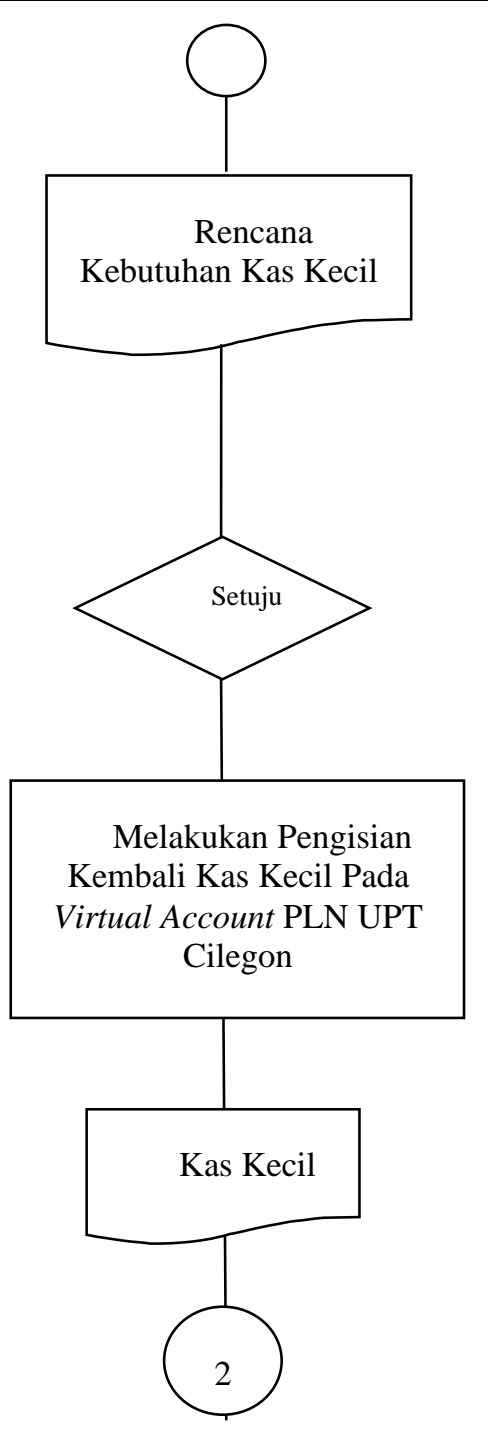

Sumber : Data diolah, 2021

Gambar 4 Prosedur Pengisian Kembali Kas Kecil

* Corresponding author's e-mail: tri.wahyudi@untirta.ac.id http://openjournal.unpam.ac.id/index.php/JIA 


\section{KESIMPULAN}

Berdasarkan hasil penelitian diperoleh kesimpulan bahwa sistem pengelolaan kas kecil yang diterapkan di PT PLN (Persero) Unit Pelaksana Proyek (UPP) Pembangkit Jawa Bagian Barat adalah sistem imprest dengan nilai pagu sebesar Rp25.000.000 per minggu. Kas kecil dikirim oleh Unit Induk melalui virtual account dan kartu ATM digunakan sebagai alat transaksi untuk penarikan tunai. Dalam pengelolaannya di PT PLN (Persero) Unit Pelaksana Proyek (UPP) Pembangkit Jawa Bagian Barat sudah berjalan mengikuti setiap prosedur yang ada. Namun, masih ditemukan hambatan yaitu tidak dapat dilakukan pengambilan kas kecil selain di hari dan jam kerja karena dihari tersebut dilakukan sweeping oleh PT PLN (Persero) Unit Induk Pembangunan (UIP) Jawa Bagian Barat sehingga saldo pada rekening bernilai nihil.

Saran untuk penelitian berikutnya adalah melakukan manajemen kas dengan kompleksitas yang lebih komprehensif tidak hanya antara unit pelaksana dengan unit induk, tetapi juga juga unit pusat, sehingga akan didapatkan pengoptimalan manajemen kas dari level atas sampai dengan bawah serta dari hulu sampai dengan hilir

\section{DAFTAR PUSTAKA}

Achyani, Y. E., \& Velayati, A. (2020). Analisa dan Implementasi Sistem Informasi Pengeluaran Kas Kecil Pada PT. Bank Bukopin Berbasis Web. Paradigma - Jurnal Komputer Dan Informatika, 22(1), 47-54. https://doi.org/10.31294/p.v22i1.7171

Atika, L., \& Pusung, R. J. (2018). Ipteks Pengelolaan Kas Kecil (Petty Cash) Pada PT PLN (Persero) Unit Induk Pembangunan Sulawesi Bagian Utara. Jurnal Ipteks Akuntansi Bagi Masyarakat, 2(02), 370-373. https://doi.org/10.32400/jiam.2.02.2018.21778

Darwis, D., Wahyuni, D., \& Dartono, D. (2020). Sistem Informasi Akuntansi Pengolahan Dana Kas Kecil Menggunakan Metode Imprest Pada PT Sinar Sosro Bandarlampung. Jurnal Teknologi Dan Sistem Informasi (JTSI), 1(1), $15-21$.

Djauhar, N., Sondakh, J. J., Kalalo, M. Y. B., Akuntansi, J., \& Ekonomi, F. (2021). Pengelolaan Dana Kas Kecil pada PT . Wahana Wirawan Manado Nissan - Datsun Martadinata. Jurnal EMBA, 9(3), 323-330.

Effendi, R. (2015). Accounting Principles. Prinsip-Prinsip Akuntansi Berbasis SAK ETAP. PT Raja Grafindo Persada.

Effendy, A. A. (2021). Optimalisasi Pengelolaan Kas Dan Manajemen Keuangan Yang Profesional Dalam Pengembangan Bisnis Di Era Kompetitif Pada Komunitas Xbank Tangerang. Dedikasi PKM, 2(1), 133. https://doi.org/10.32493/dedikasipkm.v2i1.8900

Hamizar, N. M. (2015). Intermediate Accounting. Lentera Ilmu Cendikia.

Hana, C. (2021). Evaluasi Penerapan Sistem Pengendalian Intern Penerimaan Kas Melalui Virtual Account Pada Universitas Kahuripan Kediri. Ekuivalensi,

* Corresponding author's e-mail: tri.wahyudi@untirta.ac.id http://openjournal.unpam.ac.id/index.php/JIA 
$7(1)$.

Manajemen, P. S., Ekonomi, F., \& Kuala, U. S. (2021). Pengaruh Modal Kerja Bersih , Arus Kas Operasi dan Beban Bunga Terhadap Nilai Perusahaan. Jurnal Ilmiah Mahasiswa Ekonomi Manajemen, 6(1), 92-107.

Martani, D. (2018). Akuntansi Keuangan Menengah Berbasis PSAK. Salemba Empat.

Marviana, R. D., \& Amalia, M. M. (2021). Pendeteksian Fraud Laporan Keuangan Perusahaan Perbankan Dalammasa Pandemi Covid 19. Jurnal STIE Semarang, 13(2), 32-54.

Mulyadi. (2016). Sistem Akuntansi (4th ed.). Salemba Empat.

Oktavianna, R., \& Prasetya, E. R. (2021). Analisis Manajemen Laba Yang Dipengaruhi Oleh Komite Audit dan Firm Size Perusahaan LQ45 Tahun 2015 - 2019. Jurnal Ilmiah Akuntansi, 9(1), 54-64.

Putra, D. A., \& Bakhar, M. (2021). Sistem Informasi Pencatatan Transaksi Berbasis Web Di Badan Usaha Milik Desa ( BUMDES ) Prasaja Desa Batursari , Kecamatan Batangan Kabupaten Pati. Smart Comp, 10(1), 26-29.

Romney, M.B. dan Steinbart, P. J. (2015). Pengantar Akuntans, Buku 2, Metode Akuntansi Untuk Elemen Laporan Keuangan Diperkaya Dengan Prespektif IFRS Dan Perbankan. PT Raja Grafindo Persada.

Rondonuwu sintje, U. Y. (2018). Ipteks Penerapan Akuntansi Kas Kecil pada PT. PLN (PERSERO) Rayon Manado Selatan. Ipteks Akuntansi Bagi Masyarakat, 02(02), 31-35.

Rusdi, I., \& Andriani, F. (2021). Sistem Informasi Pencatatan Arus Kas ( SIPAS ) Pada PKBM Negari 23 Kebon Melati Jakarta Menggunakan Model Waterfall. Smart Comp, 10(2).

Sari, F. I., \& Sutiono, F. (2017). Sistem Pengendalian Internal terhadap Pengelolaan Dana Kas Kecil pada PT Jasa Marga ( Persero ) Tbk Cabang Jakarta- Cikampek. Mahasiswa Bina Insani, 2(1), 87-94.

Sari, Y. P. L., \& Suprayogi, N. (2020). Strategi Manajemen Kas Perusahaan Properti Syariah Untuk Menjaga Kelangsungan Usaha. Jurnal Ekonomi Syariah Teori Dan Terapan, 7(3), 448. https://doi.org/10.20473/vol7iss20203pp448-459

Suranti, D. (2016). Perlakuan Akuntansi Kas Kecil. Journal of Applied Accounting and Taxation, 1(1), 21-24.

Suwandi, S., Hatta, M., \& Elvantonius, E. (2019). Implementasi Metode Imprest Fund Dalam Aplikasi Sistem Akuntansi Dana Kas Kecil Berbasis Web. Jurnal Soshum Insentif, 253-264. https://doi.org/10.36787/jsi.v2i2.162

Tambunan, R. M. (2013). Pedoman Penyusunan Standard Operating Procedures $(S O P)$. Maistas Publishing.

Wulandari, F. R., \& Khabibah, N. A. (2020). Analisis Pengelolaan Dana Kas Kecil pada PT Bank Negara Indonesia (Persero) Tbk KCU Magelang. Jesya (Jurnal Ekonomi \& Ekonomi Syariah), 4(1), 65-73. https://doi.org/10.36778/jesya.v4i1.285 